\title{
A Brief Historical Overview of Curriculum in Early Childhood Care and Education
}

\author{
Jenny Ritchie
}

\section{Contents}

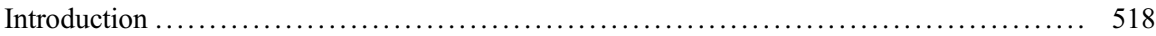

Part One: A Brief Historical Overview of Early Years' Educational Ideas ............... 519

Responsive and Progressive Twentieth-Century Innovations ................... 521

Part Two: Traditional Modes of Rearing Young Children - A Curriculum of "Guided

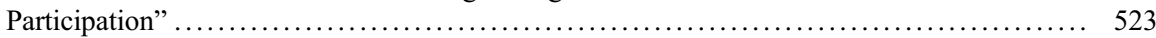

Ako: Traditional Māori Learning and Teaching in the 1930s ...................... 524

Pukapuka: A Pacific Island Culture in the 1970s ............................... 526

Part Three: Resisting Dominant Discourses ................................. 527

Kōhanga Reo: Māori Language Nests and Te Whāriki, a "Bicultural" Curriculum .......... 527

Anti-bias Curriculum: Resisting Developmentalism and the Normativization of Early

Childhood ......................................................... 528

Conclusion and Future Directions: Responding to Global Challenges ................ 531

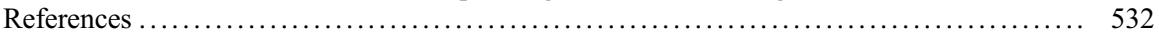

\begin{abstract}
Across time and national boundaries, infants and young children grow and learn, mastering such huge accomplishments as mobility, language, and socialization within their particular cultural milieu. This chapter traces trajectories of early childhood education curriculum, firstly identifying some of the key European theorists who informed and invented curriculum and pedagogical systems for young children. It then considers how a curriculum of "guided participation" is enacted via informal education processes in traditional communities such as those of the Māori in New Zealand, in the 1930s, and Pukapuka in the northern Cook Islands, in the 1970s. Lastly, it provides some examples of a range of particularly influential curricula, some of which have intentionally worked toward countering dominant, universalizing western discourses. These include Montessori, Reggio
\end{abstract}

\footnotetext{
J. Ritchie $(\square)$

Te Herenga Waka Victoria University of Wellington, Wellington, New Zealand

e-mail: jenny.ritchie@vuw.ac.nz
} 
Emilia, developmentally appropriate practice (DAP), Te Whāriki, Te Kōhanga Reo, the anti-bias curriculum, and outdoor early education programs. The chapter concludes by suggesting that there is much that can be learned from the study of the strengths and contributions of these various programs, historically and currently, which can inform our decisions about early childhood care and education which will sustain children, families, communities, and our planet, into the future.

\section{Keywords}

Early childhood $\cdot$ Curriculum $\cdot$ Guided participation $\cdot$ Countering dominant discourses

\section{Introduction}

This chapter begins with consideration of the terms "curriculum" and "early childhood education" followed by an explication of some of the ideas of scholars who recorded views as to the core components of early years' education. Traditional cultures, while allowing children freedom to explore, also provide opportunities for children to learn through the informal "curriculum" of observation and participation in the work of the community. Western models of early childhood education have been exported internationally while also having served as instruments for the colonization of Indigenous people. Meanwhile, the democratic ideal of the empowerment of young children to act responsibly and in concert for the collective well-being of their communities can be seen as another overarching theme that is represented in many curricula across the ages and is illustrated in some of the selected case studies of various curricula overviewed later in the chapter.

The question of what is an early childhood education "curriculum" is contested, requiring contextually specific responses (File et al. 2012; Wood and Hedges 2016). It can be viewed as both formal and informal, hidden and explicit, ranging from a boxed set of materials accompanied by a teacher's manual, to a philosophical guide accompanied by exemplars, or considered to be the full set of experiences available to the young child within the home and/or in an education setting (File et al. 2012; New Zealand Ministry of Education 1996). Early childhood curricula have drawn on a range of theoretical domains, some of which have focused on the processes of children's growth and learning and expected developmental or culturally determined outcomes, while others have been more concerned with subject knowledge and skills (Wood and Hedges 2016). The education of young children takes place in both formal and informal settings, from homes and communities to public facilities, some focusing predominantly on "child care" for working parents and others on preparation for school, with more recent recognition of the importance of integrating both care and education for all young children, from the youngest infants through to school-age children (May 2013).

One of the interesting paradoxes regarding early childhood education curricula is the tension between the long-standing recognition of the importance of the early years as foundational to future learning and life in general and the reluctance of 
governments to accept that this period of life requires educational oversight beyond that of the child's family. Along with a comparative lack of financial resourcing of this sector in relation to schooling and tertiary education, this situation has meant that there has been less emphasis on producing early childhood education curricula.

Over the centuries, scholars fascinated with the growth and learning of young children have engaged with the question of what might be "appropriate" curriculum for this period of life. Central to much of this literature is the recognition that for young children, play is a key source of their learning. As John Dewey wrote in 1933: "There is, then, nothing mysterious or mystical in the discovery made by Plato and remade by Froebel that play is the chief, almost the only, mode of education for the child in the years of later infancy" (Dewey 1933, p. 210). For Dewey, "Playfulness is a more important consideration than play" (Dewey 1933, p. 210) [italics in original]. Dewey associated this internal disposition to play with an attitude toward learning which allows children to develop not only their sense-making capacities but also their creativity and ingenuity. Part One of this chapter explores how key historical educational philosophers conceived the components of early childhood curriculum.

The scope of this chapter is such that only an admittedly selective overview can be provided. The reader may wish to pursue longer, more in-depth histories of early childhood education and curriculum (see for example: Lascarides and Hinitz 2011; May 1997; Nutbrown et al. 2008; Prochner 2009; Wolfe 2000). This chapter begins with a brief historical overview of key early childhood education curriculum theorists. This is followed by discussion of traditional modes of supporting young children's growth and development. Lastly some examples of the contestation of developmentalist discourses are provided.

\section{Part One: A Brief Historical Overview of Early Years' Educational Ideas}

Historically in many countries, learning in the early years of life has not been viewed as part of the formal education system. Young children have participated fully in the lives of the parents, siblings, and wider family and community members. This learning has been described, from a sociocultural perspective, as being informed by "guided participation" within the everyday activities of the child's family and environs (Rogoff 2003). The work of even very young children has been and continues to be a valuable contribution to sustaining the well-being of the family in many societies and countries, while the care of young children has been the shared responsibility of older siblings, parents, and/or the elders of the community. Meanwhile, there have been a range of western philosophers and scholars who have published works outlining their understandings of the ways in which adults might support the growth and learning of young children. In this section, some examples of these ideas are outlined, demonstrating some of the antecedents for early childhood curricula in the modern era. These include the recognition of the importance of the formative nature of the early years and thus early years' education; play as central in young children's growth and learning including practical play activities such as 
construction and gardening; the role of the senses along with learning in and from nature; transmission of the cultural knowledges contained in traditional stories and poetry; freedom for young children from formal lessons; the great variety in the ways that individual children learn and arrive at different readiness periods for growth and learning; and the role of the adult in both observing and supporting young children's growth and learning.

Tracing the history of curriculum in early childhood as far back as the time of the Greek philosophers Aristotle (384-322 B.C.) and Plato (427-347 B.C.), we can note that both advocated for the value of play, exercise, and stories for young children. Plato considered that play should offer practical experience that would prepare them for later life, such as "building children's houses" or gardening (as cited in Wolfe 2000 , p. 9). He also stressed the role of adult observation in enabling an understanding of children's needs and interests and to enable planning of their education accordingly.

Both Aristotle and Plato highlighted the importance of early education and environment in the preparation of future contributing citizens of their democracy, although this was focused on boys more than girls in this patriarchal society (Lascarides and Hinitz 2011). Later, the Roman writer Quintilian (A.D. 35-100) identified stages of child development and advocated that young children should be provided with moral guidance and praise, as well as tasks that suited their level of ability. The Romans viewed play as practice for later life (Lascarides and Hinitz 2011).

According to the medievalist scholar Philippe Ariès, during the Middle Ages, there was little distinction "between children and adults, in dress or in work, or in play" (1960, p. 59). However, other scholars point to the burgeoning of parenting advice books by the fifteenth century (Lascarides and Hinitz 2011). These offered a clear moral imperative that parents ensure that their young children receive an education and for parents and teachers to be good role models.

The educational philosopher Jan Amos Komensky or Comenius (1592-1628), who was born in Moravia, now part of the Czech Republic, envisioned an education which was guided by sensory experience of nature (Lascarides and Hinitz 2011; Wolfe 2000). His guide, The School of Infancy, advised that young children should have knowledge of nature, including plants and animals; of astronomy, local geography, and politics; and of household matters. Children should be encouraged to play freely, where possible with real objects. Stories and fables were to be utilized as a conveyance for moral guidance. Education should match the developmental pace of the child, and parents should provide equipment, safe spaces, and other children with whom to play (Lascarides and Hinitz 2011).

The British scholar John Locke (1632-1704) recognized the impact of an infant's early upbringing in the home as "crucial to the development of good character" (May 1997, p. 5). He also advocated for children to have "freedom to grow, play, experiment, and make mistakes" and for adults to encourage children's curiosity (Lascarides and Hinitz 2011, p. 48). Jean Jacques Rousseau (1712-1778), who lived mostly in France, advocated for the removal of the tight infant swaddling wrappings which, while inducing passivity, were undoubtedly unhygienic, unhealthy, and 
unconducive to well-being or learning. In contrast to Locke's notion of the view of the child as a "tabula rasa" or blank slate, Rousseau believed that children were born both good and free and thus should learn from their exploration within the world of nature (Wolfe 2000).

In Switzerland, Johann Heinrich Pestalozzi (1746-1827) upheld a concern for social justice, in particular for the impacts of poverty and other societal power imbalances (Wolfe 2000). Unlike previous scholars, Pestalozzi actually applied his ideas as a teacher, relishing the sense of empowerment that his pupils experienced. He had a holistic view of the child, as comprising "the hand, heart, and head" and advocating for learning through practical activity. He was against punishment, intimidation, or rewards as teaching strategies, directing teachers to reflect on their educational processes rather than blame children for inattention. He likened teachers to gardeners: "But what is the true type of education? It is like the art of the gardener under whose care a thousand trees blossom and grow" (as cited in Wolfe 2000, p. 63). He developed a curriculum of instructional methods which, once published, were widely influential.

This "garden" metaphor reappears in the work of German educator Friedrich Wilhelm August Froebel (1782-1852). Froebel, who was influenced by Pestalozzi, is acknowledged as the originator of the "kindergarten" curriculum, having coined this term (children's garden) for his schools for young children. Froebel articulated a curriculum based on his understandings of children's stages of development and designed a set of equipment (he called these "gifts") and occupations to enable this (Wolfe 2000). For Froebel, "Play is the highest phase of child development. . .for it is self-active representation of the inner. . .necessity and impulse [and] gives, therefore, joy, freedom, contentment, inner and outer rest, peace with the world" (as cited in Wolfe 2000, p. 113). His primary goal was "to lead children early to think" (as cited in Wolfe 2000, p. 114). Froebel's program of "indoor and outdoor play space, opportunities for gardening, nature study, outings, songs and games, educational playthings (the gifts), and handcrafts (the occupations) laid the foundation for early childhood curriculum as it is today" (May 1997, p. 55). All these foundational ideas regarding early childhood curriculum, albeit briefly sketched in this overview, not only challenged the norms of their day but came to have a wide-ranging influence on future iterations of formal early childhood curricula.

\section{Responsive and Progressive Twentieth-Century Innovations}

The infant schools of the late nineteenth and early twentieth centuries were a response to the realities of their particular contexts, many being posited as philanthropic or reformist remedies for the social ills of young children being left unattended while carefully couched in ways that would not challenge the doctrine of women's place being in the home (May 1997). Dr. Maria Montessori's (1870-1952) began her Casa dei Bambini in 1907. The Italian scholar, feminist, peace activist, and innovative progressive educator was the first Italian woman who gain a medical degree. After becoming interested in education, she did further study in experimental 
psychology and "pedagogical anthropology," applying her observational skills and critical analysis to developing an extensive pedagogical philosophy and curriculum for the education of young children. Montessori had a strong sense of social justice, extending the notion of human rights to both women and children (Wolfe 2000). She was critical of the "monotonous servitude" and competitive nature of schooling which failed to counter social ills such as war and racism (Lascarides and Hinitz 2011, pp. 163-164). She considered the young child to have an "absorbent mind" and that infancy was the time for education of the senses as well as social education (Lascarides and Hinitz 2011, pp. 148-149). Her understandings of young children's growth and development recognized what she termed "sensitive periods" in which children focus on particular interests or objectives, such as walking, talking, and "becoming involved in understanding the civil rights of others and establishing a community with them" (Maria's son Mario Montessori, as cited in Lascarides and Hinitz 2011, p. 151). Montessori was critical of the schooling methods of the time which required children to sit for hours in rows of benches or desks, while their teachers "pour out dried facts" into their heads, manipulating them with prizes and punishments (Montessori 1914, p. 21). She wrote that "In such a school the children, like butterflies mounted on pins, are fastened each to his place, the desk, spreading the useless wings of barren and meaningless knowledge which they have acquired" (Montessori 1914, p. 14).

Montessori's program employed neither prizes nor punishment. It aimed to heighten children's powers of observation, particularly of "the phenomena of life," and to inspire children with a "feeling for nature" via an "education of the senses" (Montessori 1914, pp. xi-xii). Her "method" included gardening and horticulture, the careful use of a range of purpose-specific, "didactic" (self-correcting) materials, along with a set of exercises for everyday practical life such as sweeping, sorting and stringing beads, and shoelace tying. Her program, initially established for poor children in Italy, became popular with middle-class families around the world, but was also criticized for its lack of creativity, cooperation, and free play (May 1997).

Another original and influential Italian articulation of early childhood curriculum is that of the philosophy developed later in the twentieth century, under the leadership of Loris Malaguzzi (1920-1994) in post-World War II in the city of Reggio Emilia in Northern Italy. It is renowned for its honoring of children's creativity and collectivity and its valuing of the environment and aesthetics. Children are viewed as active co-constructors of knowledge, as social beings, and as rights holders (Soler and Miller 2003). Listening is considered by Carlina Rinaldi, who succeeded Malaguzzi as the director of Reggio Emilia services, to be at the heart of this curriculum, serving as a metaphor for dispositions of openness, curiosity, sensorial receptivity, and awareness of interior and exterior emotions (Rinaldi 2006). The curriculum created in Reggio Emilia has, like the Montessori method, become popular in other countries. Particular aspects that have been adopted include a particular aesthetic incorporating art using recycled materials, the facilitation of long-term projects led by children, and careful, detailed pedagogical documentation (Eckhoff and Spearman 2009). The importing of curricula developed elsewhere, sometimes without authenticity and often as a marketing ploy, has been critiqued 
(Johnson 2000). Yet the transfer of curricular and pedagogical methods and systems across eras and cultures is undoubtedly a feature of early childhood curricula.

As formal early childhood curriculum began to be produced, themes raised by these early scholars can be identified, such as the recognition of different developmental readiness periods and the value of children learning through sensory exploration, having freedom to grow and learn through play and creativity, and connecting with the natural world. More recently, western models reflecting white western middle-class values such as "developmentally appropriate practice" have been critiqued for attempting to impose normativizing expectations that are not necessarily relevant or appropriate across diverse cultures (Mallory and New 1994; O'Loughlin 1992). In the remaining sections of this chapter, a trajectory of both informal and formal "early childhood education" is addressed, with reference to a range of different cultures and societies, both western and non-western, presented in the form of selected brief case studies.

\section{Part Two: Traditional Modes of Rearing Young Children - A Curriculum of "Guided Participation"}

All curricula are contextually derived and culturally and historically located. In the area of early childhood care and education, different cultural groups have historically developed different ways of rearing young children. In many traditional societies, young children were not segregated into separate child-focused arenas, but participated alongside adults to whatever extent they were capable. In the many countries that have been colonized, the imposition of the expectations, educational practices, and languages of the colonizers has impacted on the experiences, including learning opportunities, available for young children. As Barbara Rogoff notes, "Colonial education was central to empire building" (Rogoff 2003, p. 344). Inculcating western religious beliefs was a fundamental tool of the colonizers in their "civilizing mission," based in their assumption of superiority and faith in their own values and belief systems as being the "One Best Way" (May et al. 2014). Traces of this assumption can be seen in curricula in early childhood that determine normative expectations for child development based on western values and research, which again ignore the diversity of experience, histories, beliefs, and knowledges held by those in traditional societies such as Indigenous peoples. In the rest of this chapter, selected examples are offered to illustrate some of the diverse manifestations of both formal and informal early childhood education curricula which have provided "counter-narratives" to dominant discourses (Wisneski 2012).

"Guided participation" is the phrase coined by the sociocultural theorist Barbara Rogoff to describe the way children learn within and from their sociocultural contexts (Rogoff 2003). It includes not only intentional instruction but also the ways in which "children participate in the values, skills, and practices of their communities" by simply being present alongside others, observing, listening, and modelling their behaviors on those around them. Rogoff describes how in her cross-cultural studies: 'Bridging between toddlers' and parents' understanding 
appeared consistently in the widely different communities studied" (Rogoff 2003, p. 285). Their interactions involved a shared agenda and parents' interpretation of preverbal children's nonverbal communication, with reciprocal "readings" of emotional contexts. Rogoff emphasizes the active role that even very young children play in their own learning and socialization.

The values and beliefs of caregivers, the types of community practices, and the extent to which children can exercise their own choices all impact to determine the nature and range of experiences in which they participate or observe. In turn, observant caregivers are able to structure children's involvement by scaffolding the children in increasing levels and depths of engagement. Narratives in the form of traditional stories, genealogies, songs, proverbs, and artwork are sources of knowledge for both intentional and peripheral instruction and learning. Activities that contribute to the well-being of the collective, such as sourcing and preparing foods, also provide a rich context for learning and the transmission of traditional knowledges. Opportunities for children to practice their new learning also feature as important within this sociocultural theoretical perspective. This can occur both in routines, whereby even very young children can serve food to others, for example, or during times when children are able to play freely, often away from the adult gaze. Play enables children to "try on" and practice adult roles and language formats. Children often share their own unofficial curriculum of games and expectations aside from the adult gaze. In this sociocultural view, "curriculum" is not merely a written set of expectations for transmission by educators, but a wider assemblage of informal, contextually and culturally derived set of experiences, values, narratives, and practices.

Two short case studies of traditional early childhood learning follow, both of which illustrate the notions of guided participation as outlined above. One draws from the work of educationalist Rangimarie Rose Pere's (1983) description of her rural Māori childhood in New Zealand in the 1930s. The second draws upon the ethnographic work of Robert Borofsky to describe the informal curriculum for early learning among the people of the Pacific Island of Pukapuka in the 1970s.

\section{Ako: Traditional Māori Learning and Teaching in the 1930s}

Ako is the Māori term for the reciprocal process of learning and teaching. Māori educationalist Rangimarie Rose Pere was raised by her grandparents in a small traditional Māori community in Ohiwa, near Lake Waikaremoana. She describes her early childhood learning experiences as follows:

I slept, ate, played, worked and learnt alongside four generations, and was never excluded from anything my grandparents were involved with, including attending celebrations, tangihanga (ceremonial mourning), and many other gatherings. I learnt through observation and participation. It was my grandparents' generation, and older, who influenced most of my learning in those early formative years. (Pere 1983, p. 2) 
The Māori value of manaakitanga includes the obligation to care; to be kind, respectful, and generous; and to offer good hospitality (Benton et al. 2013). Children were expected to "learn how graciously to give or accept kindness and hospitality right from the time they could help with the preparation of food" (Pere 1983, p. 66). Even young children participated in the work of hosting guests, each contributing "at their own level of competence" (Pere 1983, p. 39). Children were expected to be polite and respectful, and humility and observation skills were valued:

Consideration and respect for other people is developed at an early stage in a child's upbringing through the protocol that applies to hui. The first concern is for people and their needs, so one learns to observe people very closely.(Pere 1983, pp. 39-40)

Similarly, children participated alongside adults in ensuring the sustenance for the well-being of the extended family:

The planting, harvesting and storing of crops, and the need to know and respect the land were all part of the children's learning. The children were exposed to patterns of regular activity, For example, seasons, plant and animal rhythms, family and community gatherings. These patterns of learning were necessary and important. (Pere 1983, p. 50)

Elders, the highly respected repositories of tribal knowledge, taught children their "history, mythology, tribal and local legends, tribal sayings, waiata (variety of chants and songs), genealogy, karakia (invocations), various crafts, hand-games and other leisurely pursuits" (Pere 1983, p. 49). This teaching began in utero and continued in the form of "chants and songs that lulled babies and children off to sleep" that contained genealogical knowledge and detailed accounts of their ancestors' successes as well as failures (Pere 1983, p. 53). Spiritual well-being as a vitally important part of this learning underpinned all activities and spiritual learning was present from birth:

Babies and children developed an appreciation of their inherent spirituality through being exposed to such things as karakia (incantations, invocations), or to people talking about their own spiritual experiences. This is a natural part of everyday living. The spiritual world became just as meaningful and present for the children as the physical world that surrounded them.

Pere highlights "the warmth and affection that traditional Maori people have for children, including babies" (Pere 1983, p. 59). She states that "children were acknowledged as having rights and could always find a sanctuary somewhere within the kinship group if there was strife at home" (Pere 1983, p. 60). Pere explains that for Māori, "Sensual experiences are encouraged, including the development and usage of intuitive intelligence" (Pere 1983, p.68). Furthermore, "Recognition and respect are given to what the child already knows" (Pere 1983, p. 70). Lastly, in accordance with the collectivist nature of traditional Māori society: 
[whilst] the individuality of each child is fostered and encouraged... the individual learns that the quality of her own life and the survival of the whole are dependent on the contribution she makes to the group and on how well she adjusts to the demands that the group imposes. (Pere 1983, p. 70)

The rich descriptions provided by Rose Pere demonstrate a child-centered informal learning curriculum in action, the processes of guidance and participation serving to prepare the child to take her place knowledgeably and confidently within the genealogical pathway paved by her ancestors.

\section{Pukapuka: A Pacific Island Culture in the 1970s}

The Polynesian atoll of Pukapuka in the northern Cook Islands was in the late 1970s the site for ethnographer Robert Borofsky's work (Borofsky 1987), which provides another example of an informal curriculum of guided participation for young children in which learning occurs "within situationally relevant contexts" (Borofsky 1987, p. 78). As in Pere's narrative above, on Pukapuka children learned much through the stories related by their elders, which children were eager to hear.

As with Māori and other Polynesian societies, children were included as of right in most of the everyday activities of their families and community. Observation and listening were key strategies for both participation and learning. Taavini reported that as a child:

I mainly watched the people making things and then I would try myself to do it. I would try doing it and it would be correct. That is the way I learned making hats; we (taua) would watch the people who knew how to make hats; then we would know how to make them. (as cited in Borofsky 1987, p. 81)

Listening was valued more highly than questioning. In fact, "extensive questioning by children is generally discouraged" (Borofsky 1987, p. 83). An elder related how she had learned through observation, but without questioning:

I learned by observation while next to... the old people as they made these things. I would watch and then I would know how to make them. I did not ask people questions. (as cited in Borofsky 1987, p. 81)

Neither direct instruction nor direct praise was apparent as strategies to foster learning. Unlike in traditional Māori communities where children were not punished (Salmond 1991; Smith 1995), on Pukapuka, children were physically beaten. Children however perceived themselves to be agentic learners, Borofsky having noted, for example, children telling him that they had deciphered the names of different fish on their own. Repeated observation and careful listening were the socially valued processes whereby young children eventually acquired mastery. 


\section{Part Three: Resisting Dominant Discourses}

In this final section, we consider some examples of specific early childhood curriculum that deliberately set out to challenge dominant discourses. The New Zealand examples of the Kōhanga Reo movement and Te Whāriki: He whāriki mātauranga mō ngā mokopuna o Aotearoa: Early childhood curriculum (New Zealand Ministry of Education 1996) both demonstrate resistance to colonialist models which had suppressed the Indigenous culture and language. Lastly, the Anti-Bias Curriculum (Derman-Sparks and the A.B..C. Task Force 1989) from the 1980s in California, USA, proactively seeks to discuss issues of racism, culture, gender, and ableism.

\section{Kōhanga Reo: Māori Language Nests and Te Whāriki, a "Bicultural" Curriculum}

The Kōhanga Reo movement is a response to the threat of the loss of Māori language that was seen to be "dying out" by the 1970s due to the imposition of the British colonialist education system (Benton 1997). It was initiated in 1982, by Māori rather than government, to bring Māori elders who were the remaining speakers of the language together with infants and young children in order that a new generation of Māori speakers would be fostered. The curriculum of Te Kōhanga Reo has focused primarily on the support and fostering of te reo (the Māori language) and of whānau (extended families). Te Kōhanga Reo can be viewed as a Māori response to restore their mana (pride, esteem) and that of their language, in defiance of an education system that had almost destroyed the language as well as failing Māori educationally (Waitangi Tribunal 1986).

The first New Zealand national early childhood curriculum, Te Whāriki (New Zealand Ministry of Education 1996), received impetus from Te Kōhanga Reo (TKR), with two of the four co-writers being nominated by the TKR National Trust (Nuttall 2003). The draft document (New Zealand Ministry of Education 1993) stipulated that in addition to considering "developmentally appropriate" practice, early childhood education in Aotearoa/New Zealand was to reflect nationally, culturally, educationally, and individually appropriate learning experiences. Both the 1993 draft and 1996 curriculum aimed to contribute toward the sustenance of Māori language and culture, making these visible and affirming their value for children from all cultural backgrounds.

The acknowledgment of the importance of "culturally appropriate experiences" recognized that:

One of the purposes of the curriculum is to make available to the next generation the knowledge, skills, and attitudes which are regarded as valuable by their culture. Different cultures have different child-rearing patterns, beliefs and traditions... There may be differences in the way they make sense of their world, communicate with each other, and plan and live their lives. (New Zealand Ministry of Education 1993, p. 14) 
The 1996 Te Wharriki defined "curriculum" as "the sum total of the experiences, activities, and events, whether direct or indirect, which occur within an environment designed to foster children's learning and development" (New Zealand Ministry of Education 1996, p. 10). Te Wharriki was positioned as the first "bicultural" curriculum statement developed in New Zealand (p. 7), in its recognition that "In early childhood education settings, all children should be given the opportunity to develop knowledge and an understanding of the cultural heritages of both partners to Te Tiriti o Waitangi," recognizing the status of both the Indigenous Māori and the settler population (p. 9). It was inclusive to all children and families' and their home languages and cultures, requiring that "The languages and symbols of their own and other cultures are promoted and protected" (p.16). It built on earlier philosophical and pedagogical approaches in recognizing the value for children in play and exploration, insisting that "their play is valued as meaningful learning and the importance of spontaneous play is recognised" (p. 16). It went further pedagogically, in asking teachers to take a dispositional approach, fostering in children dispositions for learning such as curiosity and persistence, and in encouraging children to develop working theories that expressed their understandings as they made sense of their worlds. Threads of the ideas of western theorists such as Friedrich Froebel, Urie Bronfenbrenner, and Jerome Bruner were interwoven within a "whāriki" (woven flax mat) derived from Māori philosophy. Traces of developmentalism were still visible, if not explicitly so, in the taken-for-granted assumptions underlying much early childhood practice in New Zealand, as elsewhere in the west at this time. As Farquhar and Fleer wrote in 2007 of both Australian and New Zealand early childhood education: "We have as yet not seriously disrupted the western developmental perspectives as the main and only view of early childhood education" (Farquhar and Fleer 2007, p. 42). The following example outlines a curriculum that deliberately sought to challenge dominant discourses regarding gender, culture, and ableism.

\section{Anti-bias Curriculum: Resisting Developmentalism and the Normativization of Early Childhood}

Developmental theory has been hugely influential in western early childhood education theory and practice. It was informed by the work of developmental psychologists such as Stanley Hall (1846-1924) in the USA and the French biologist and psychologist, Jean Piaget (1896-1980). Developmental theory was primarily focused on cognition and cognitive development (Vejleskov 1999). It resulted in the expectations of "normal" stages of development, which were to be used to assess children's progress. The Piagetian child came to be conceptualized as an individual "researcher" whose development would gradually advance through predictable stages as the child continued to explore "his" world. The difficulties of the influence of such a dominant discourse on curriculum and pedagogy can be seen in whereby in Piaget's thinking, a characteristic of the pre-operational child (aged between 2 and 7 years) is egocentrism. If this assumption informs curriculum and pedagogy, there 
may be little attempt to encourage empathy and cooperation, as these might be considered developmentally inappropriate aspirations. Thus, the "theory... creates its own truth" (Ingleby 1986, p. 312). The pervasiveness of applications of Piagetian child development theory is an example of the proclivity of western researchers to claim the right to name the world and, in naming the world, to create "truths" which have come to be applied as "universal knowledge" (Ingleby 1986).

Meanwhile, the work of theorists Jerome Bruner (1915-2016), Urie Bronfenbrenner (1917-2005), and Lev Vygotsky (1896-1934) challenged curriculum and pedagogy to address sociocultural considerations of early education processes, broadening the individualized, western lens of developmental psychology. In 1990 the US National Association for the Education of Young Children (NAEYC) produced a document: "Developmentally appropriate practice in early childhood programs serving children from birth through age 8" (Bredekamp 1990). While hugely influential in the USA and elsewhere, developmentally appropriate practice (DAP) was criticized for its normative approach which lacked recognition of cultural and socioeconomic differences (Cross 1995; Jipson 1991; Lubeck 1994; O'Loughlin 1992). In response to such challenges, the subsequent edition (Bredekamp and Copple 1997) "explicitly acknowledges the powerful influence of [social and cultural] context on all development and learning" (Bredekamp and Copple 1997, p. 41). Fendler has pointed out that "flexible is not necessarily free, developmentality is not necessarily appropriate, and interaction is not necessarily democratic" (Fendler 2001, p. 121, as cited in Farquhar and Fleer 2007, p. 34). Developmentalism has continued to be critiqued as "privileging culturally narrow and/or ethnocentric individualistic goals" for children (Mac Naughton 2003, p. 177).

Other theorists, such as Pierre Bourdieu and Jean-Claude Passeron (Bourdieu and Passeron 1990; Edgerton and Roberts 2014), Michel Foucault (1980), and Antonia Darder (1991), have challenged educators to recognize the hidden power effects associated with regimes of truth and the way in which the cultural capital of certain groups of society is ignored by members of the dominant culture. Inequities were recognized as being perpetuated through pedagogical processes that reinforced the status quo, with curriculum being designed and delivered by the dominant groups with society, ignoring the invisibilization of the languages and cultures of Indigenous and other cultures and the impact this had on those children.

In response to this issue, a range of pedagogical approaches sought to recognize the centrality of culture in children's identities and learning, such as:

- Culturally relevant pedagogy (Bartolome 1994; Bowman 1991; Darder 1991; Ladson-Billings 1995; O’Loughlin 1995)

- Culturally responsive pedagogy (Osborne 1991)

- Culturally sensitive approaches (Gonzalez-Mena 1992; Mangione et al. 1993)

- Culturally consistent and inclusive programs (Booze et al. 1996)

- Culturally congruent critical pedagogy (Hyun 1998)

- Educationally effective cultural compatibility (C. Jordan 1985; Cathie Jordan 1995) 
- Culturally appropriate early childhood education (New Zealand Ministry of Education 1996)

All of these approaches recognized the "problem of discontinuity" between home and educational setting experienced by learners who are not members of the white middle-class dominant culture (Ladson-Billings 1995, p. 159). It is clear that uneven power effects will continue to pervade early childhood practice, unless the traces of developmentalism guiding frameworks and curriculum are overtly challenged.

Many members of the writing team of the Anti-bias Curriculum: Tools for Empowering Young Children (Derman-Sparks and the A.B..C. Task Force 1989) were associated with Pacific Oaks College, an early childhood teacher education provider in Pasadena, California, that was founded with strong Quaker values of community, equality, peace, and progressive education. This curriculum provided both a philosophical rationale and practical pedagogies for challenging "racism, sexism, and handicapism" (Derman-Sparks and the A.B..C. Task Force 1989, p. ix). Not only did it aim at empowering children from different ethnic backgrounds and genders and with disabilities; it also challenged the assumptions of privilege of those who were white, male, and able-bodied. It was upfront about its progressive political positioning:

[The A.B..C.] "is values based: Differences are good; oppressive ideas and behaviors are not. It sets up a creative tension between respecting differences and not accepting unfair beliefs and acts. It asks teachers to confront troublesome issues rather than covering them up. (Derman-Sparks and the A.B..C. Task Force 1989, p. x)

As an example of its stance, the A.B..C. Curriculum critiqued "multicultural" approaches as potentially being a form of "tourist curriculum" that "teaches about cultures through celebrations and through such "artifacts" of the culture as food, traditional clothing, and household implements," often on a special day each year, such as Chinese New Year (Derman-Sparks and the A.B..C. Task Force 1989). In this mode, the dominant white western culture remains ubiquitously invisible, and its privilege remains unchallenged. The A.B..C. Curriculum required teachers to proactively create an anti-bias environment, utilizing images, books, and equipment that is representative of diverse children and families and eliminating stereotypical materials. Engagement with actual community events and activism was recommended, as was critique of the misrepresentation of First Nations Peoples that was often perpetuated during celebrations such as "Thanksgiving."

Furthermore, it asked teachers to similarly interrogate the nature of their own interactions. The use of narratives enacted by "persona" dolls was recommended as a technique to illustrate how children with different abilities and from diverse backgrounds might experience discriminatory behavior, often mirroring actual experiences in the classroom, such as children using the term "Chinese" as an insult. The proactive use of the personal dolls aimed at honoring children's emotions, enabling their fears to be recognized and validated in a safe and respectful manner. 
The A.B..C. Curriculum conformed to developmentalist discourse in providing sets of "developmental tasks and guidelines for child-teacher interactions" for the various age groups. However, using the anti-bias lens opened up spaces for conversations, such as in the guidelines for 2-year-olds, which suggested that diaper changing and toileting are opportunities for casual conversations about aspects such as gender identity and skin color. Both baby dolls and art materials which have a range of skin colors were recommended for supporting this learning.

Engagement with parents was advocated, beginning with establishing open dialogue and the creation of safe spaces for parents to engage with issues of discrimination and privilege in their own and their children's lives. As with Te Whäriki, parents were to be involved with curriculum development, implementation, and evaluation.

\section{Conclusion and Future Directions: Responding to Global Challenges}

Curricula for young children reflect the history, politics, and cultures of the society in which they have emerged, including the educational ideas that were current, along with beliefs and practices in relation to young children, families, and childrearing, attitudes with regard to the role of women, and views regarding the responsibilities of government (May 2013).

Historically, young children were very much an intrinsic part of the everyday life of the community, while contemporary western models of early childhood curriculum tend to separate even very young children to be cared for in educational settings outside of the home. The quality of these experiences is dependent not only on the mandated curriculum but also on the qualifications of the teachers, the ratios of teachers to children, the group size, and the environment and resourcing. The brief overview of selected early childhood education curricula outlined above has highlighted philosophies that aim beyond merely supporting children's physical and cognitive development, toward supporting children to learn dispositions of respect, fairness, and concern for others. Continuities traced across the curricula examined include a respect for young children's freedom, rights, and agency as learners and as contributing members of a community; approaches that foster dispositions such as playfulness, observation, curiosity, and attunement with nature; and intergenerational transmission of culturally valued knowledge via legends, songs, stories, and poetry.

Currently, the UNESCO Sustainable Development Goals call upon educators in all the world's countries to embrace curricula that will enhance children's dispositions for caring for fellow citizens and for our planet, oceans, lands, forests, wetlands, and living creatures (UNESCO 2017; UNESCO Global Education Monitoring Project 2016). There is a growing global movement in response to concern for our planet's well-being that suggests that young children should have experiences in the outdoors on a regular basis, thus engendering a disposition of 
attunement with the natural world and concern for the sustenance of biodiversity. Responsiveness to this concern is evident in the Australian early years framework, Belonging, Being and Becoming (Australian Government Department of Education Employment and Workplace Relations 2009), and in the recently refreshed New Zealand early childhood curriculum Te Whāriki (New Zealand Ministry of Education 2017). Other models such as Forest Schools in Europe, the UK, and elsewhere, along with bush kinder in Australia, provide similar opportunities for children to experience the outdoors on a regular basis (Elliott and Chancellor 2014; Waite et al. 2016). This chapter has provided illustrative examples of different forms and focuses of early childhood curricula, with the intention of generating reflection and discussion on the nature of curriculum, the groups that are served by these, and the potential for these benefits to contribute to the wider well-being of collectives, inclusive of the global community of life into the future.

\section{References}

Ariès P. Centuries of Childhood. Harmondsworth: Penguin; 1960.

Australian Government Department of Education Employment and Workplace Relations. Belonging, being and becoming. The early years learning framework for Australia. Barton: Commonwealth of Australia; 2009. Retrieved from https://www.education.gov.au/early-yearslearning-framework.

Bartolome LI. Beyond the methods fetish: toward a humanizing pedagogy. Harv Educ Rev. 1994;64(2):173-94.

Benton R. The Maori language. Dying or reviving? Wellington: NZCER; 1997. Retrieved from http://www.nzcer.org.nz/system/files/The_Maori_Language_dying_reviving.pdf

Benton R, Frame A, Meredith P. Te Mātāpunenga. A compendium of references to the concepts and institutions of Māori customary law. Wellington: Victoria University Press; 2013.

Booze R, Greer C, Derman-Sparks L. Creating culturally consistent and inclusive early childhood programs for all children and families. Child Care Inf Exch. 1996;1:60-2.

Borofsky R. Making history. Pukapukan and anthropological constructions of knowledge. Cambridge: Cambridge University Press; 1987.

Bourdieu P, Passeron JC. Reproduction in education, society, and culture. London: Sage; 1990.

Bowman B. Educating language minority children: challenges and opportunities. In: Kagan SL, editor. The care and education of America's young children: obstacles and opportunities. Chicago: University of Chicago; 1991. p. 17-29.

Bredekamp S. Developmentally appropriate practice in early childhood programs serving children from birth through age 8. Washington, DC: National Association for the Education of Young Children; 1990.

Bredekamp S, Copple C. Developmentally appropriate practice in early childhood programmes. Washington, DC: National Association for the Education of Young Children; 1997.

Cross T. The early childhood curriculum debate. In: Fleer M, editor. DAPcentrism: challenging developmentally appropriate practice. Watson: Australian Early Childhood Association; 1995. p. 87-108.

Darder A. Culture and power in the classroom: a critical foundation for bicultural education. Westport: Bergin and Garvey; 1991.

Derman-Sparks L, The A.B..C. Task Force. Anti-Bias curriculum. Tools for empowering young children. Washington, DC: National Association for the Education of Young Children; 1989. 
Dewey J. How we think. A restatement of the relation of reflective thinking to the educative process. Boston: DC Heath and Company; 1933.

Eckhoff A, Spearman M. Rethink, reimagine, reinvent: the Reggio Emilia approach to incorporating reclaimed materials in children's artworks. Art Educ. 2009;62(2):10-6. https://doi.org/ $10.2307 / 27696325$.

Edgerton JD, Roberts LW. Cultural capital or habitus? Bourdieu and beyond in the explanation of enduring educational inequality. Theory Res Educ. 2014;12(2):193-220.

Elliott S, Chancellor B. From forest preschool to Bush Kinder: an inspirational approach to preschool provision in Australia. Australas J Early Childhood. 2014;39(4):45-53.

Farquhar S, Fleer M. Developmental colonisation of early childhood education in Aotearoa/New Zealand and Asutralia. In: Keesing-Styles L, Hedges H, editors. Theorising early childhood practice. Emerging dialogues. Castle Hill: Pademelon; 2007. p. 27-49.

File N, Mueller JJ, Wisneski DB. Curriculum in early childhood education: re-examined, rediscovered, renewed. New York: Routledge; 2012.

Foucault M. Power/knowledge. Selected interviews and other writings 1972-1977 (Ed. Gordon C). New York: Harvester Wheatsheaf; 1980.

Gonzalez-Mena J. Taking a culturally sensitive approach to infant-toddler programs. Young Child. 1992;47(2):4-18.

Hyun E. Making sense of developmentally and culturally appropriate practice (DCAP) in early childhood education. New York: Peter Lang; 1998.

Ingleby D. Development in social context. In: Richards M, Light P, editors. Children of social worlds. Cambridge: Polity Press; 1986. p. 297-317.

Jipson J. Developmentally appropriate practice: culture, curriculum, connections. Early Educ Dev. 1991;2(2):120-36.

Johnson R. Colonialism and cargo cults in early childhood education: does Reggio Emilia really exist? Contemp Issues Early Child. 2000;1(1):61-78. https://doi.org/10.2304/ ciec.2000.1.1.8.

Jordan C. Translating culture: from ethnographic information to educational program. Anthropol Educ Q. 1985;16(2):105-23.

Jordan C. Creating cultures of schooling: historical and conceptual background of the KEEP/Rough Rock collaboration. Biling Res J. 1995;19(1):83-100.

Ladson-Billings G. But that's just good teaching! The case for culturally relevant pedagogy. Theory Pract. 1995;34(3):159-65.

Lascarides VC, Hinitz BF. History of early childhood education. New York: Routledge; 2011.

Lubeck S. The Politics of developmentally appropriate practice: exploring issues of culture, class, and curriculum. In: Mallory BL, New RS, editors. Diversity \& developmentally appropriate practices: challenges for early childhood education. New York: Teachers College Press; 1994. p. 17-43.

Mac Naughton G. Shaping early childhood. Learners, curriculum and contexts. Maidenhead: Open University Press; 2003.

Mallory BL, New RS, editors. Diversity \& developmentally appropriate practices. Challenges for early childhood education. New York: Teachers College Press; 1994.

Mangione PL, Lally JR, Singer S. Essential connections: ten keys to culturally sensitive child care. Sacramento: Far West Laboratory for Educational Research and Development; 1993.

May H. The discovery of early childhood. Auckland: Bridget Williams Books/Auckland University Press; 1997.

May H. The discovery of early childhood. 2nd ed. Wellington: NZCER Press; 2013.

May H, Kaur B, Prochner L. Empire, education, and indigenous childhoods. Nineteenth-century missionary infant schools in three British colonies. Abingson: Routledge; 2014.

Montessori M. The Montessori method. Scientific pedagogy as applied to child education in "the children's houses" with additions and revisions by the author (trans: George AE). London: William Heinemann; 1914.

New Zealand Ministry of Education. Te Whāriki, draft guidelines for developmentally appropriate programmes in early childhood. Wellington: Learning Media; 1993. 
New Zealand Ministry of Education. Te Whāriki. He whāriki mātauranga mō ngā mokopuna o Aotearoa: early childhood curriculum. Wellington: Learning Media; 1996. Retrieved from https://education.govt.nz/assets/Documents/Early-Childhood/Te-Whariki-1996.pdf.

New Zealand Ministry of Education. Te Whāriki. He whāriki mātauranga mō ngā mokopuna o Aotearoa. Early childhood curriculum. Wellington: Ministry of Education; 2017.

Nutbrown C, Clough P, Selbie P. Early childhood education. History, philosophy and experience. London: Sage; 2008.

Nuttall J, editor. Weaving Te Whāriki. Aotearoa New Zealand's early childhood curriculum document in theory and practice. Wellington: NZCER; 2003.

O'Loughlin M. Appropriate for whom? A critique of the culture and class bias underlying Developmentally Appropriate Practice in early childhood education. Paper presented at the 3rd Reconceptualizing early childhood education: research, theory, and practice conference: reclaiming the progressive agenda, Chicago; 1992.

O'Loughlin M. If not 'child development', then what? Six propositions concerning children, their worlds, and the language we use to describe them. Paper presented at the Reconceptualizing early childhood education: research, theory, and practice. Fifth interdisciplinary conference, Santa Rosa; 1995.

Osborne B. Towards an ethnology of culturally responsive pedagogy in small-scale remote communities: Native American and Torres Strait Islander. Qual Stud Educ. 1991;4(1):1-17.

Pere RR. AKO. Concepts and learning in the Māori tradition. Working paper no 17. Hamilton: Department of Sociology, University of Waikato; 1983.

Prochner L. A hisotry of early childhood education in Canada, Australia, and New Zealand. Vancouver: UBC Press; 2009.

Rinaldi C. Dialogue with Reggio Emilia. London: Routledge; 2006.

Rogoff B. The cultural nature of human development. Oxford: Oxford University Press; 2003.

Salmond A. Two Worlds: first meetings between Mäori and Europeans, 1642-1772. Auckland: Viking; 1991.

Smith LT. The colonisation of Māori children. Youth Law Rev, August/September/October. 1995:8-11.

Soler J, Miller L. The struggle for early childhood curricula: a comparison of the English Foundation Stage Curriculum, Te Whāriki and Reggio Emilia. Int J Early Years Educ. 2003;11(1):57-68. https://doi.org/10.1080/0966976032000066091.

Tribunal W. Report of the waitangi tribunal on the Te Reo Maori Claim (WAI 11). Wellington: GP Publications: Waitangi Tribunal; 1986. Retrieved from http://www.justice.govt.nz/tribunals/ waitangi-tribunal

UNESCO. Education for sustainable development goals. Learning objectives. Paris: United Nations Educational, Scientific and Cultural Organisation; 2017. Retrieved from http://unesdoc.unesco. org/images/0024/002474/247444e.pdf

UNESCO Global Education Monitoring Project. Education for people and planet: creating sustainable futures for all. 2016. From http://unesdoc.unesco.org/images/0024/002457/245752e.pdf

Vejleskov H. Developmental psychology and early childhood education. Eur Early Child Educ Res J. 1999;7(1):23-34. https://doi.org/10.1080/13502939985208301.

Waite S, Bolling M, Bentsen P. Comparing apples and pears?: a conceptual framework for understanding learning through comparison of English Forest Schools and Danish udeskole. Environ Educ Res. 2016;22(6):868-92.

Wisneski DB. "Silent voices of knowing" in the history of early childhood education and curriculum. In: File N, Mueller JJ, Wisneski DB, editors. Curriculum in early childhood education: reexamined, rediscovered, renewed. New York: Routledge; 2012. p. 3-13.

Wolfe J. Learning from the past. Historical voices in early childhood education. Mayerthorpe: Piney Branch Press; 2000.

Wood E, Hedges H. Curriculum in early childhood education: critical questions about content, coherence, and control. Curric J. 2016;27(3):387-405. https://doi.org/10.1080/ 09585176.2015.1129981. 